\title{
Solid Waste Generation and Management Techniques In Ado-Ekiti, South- West, Nigeria
}

\author{
Ogunleye, Olusesan Sola \\ Uzoma, Emmanuel Sunny \\ Department of Geography and Planning Science, \\ Ekiti State University, Ado-Ekiti, Ekiti State, Nigeria
}

Doi:10.19044/esj.2018.v14n35p290 URL:http://dx.doi.org/10.19044/esj.2018.v14n35p290

\begin{abstract}
Solid waste management is a contemporary issue and as such has attracted a lot of attention worldwide. In Nigeria today, the government and other relevant authorities seemed to be helpless in finding the best alternative measure to adopt in ameliorating the negative impact of wastes on the environment. It is on this note that this paper examined solid waste management techniques in Ado-Ekiti, South West, Nigeria. Data for the study were collected from both primary and secondary sources. The methodology for primary data collection were preliminary study, observation, and administration of questionnaires. 400 copies of questionnaire were administered on randomly selected respondents from five different zones in the study area. Secondary data were collected mainly from Ekiti State Waste Management Authority, National Bureau of Statistics as well as from GIS Spatial Nigeria Limited. Data were analysed using tables, frequencies and percentages, as well as Chi-square analysis. The hypothesis generated were tested at $(\mathrm{p}<0.05)$ level of significance. It was discovered that there was a significant difference in the method of waste disposal adopted in the study area $(\chi 2=3508.074, \mathrm{df}=25, \mathrm{p}<0.05)$. The study recommends a reduction in the cost of waste collection by the Waste Management Companies, this will encourage the people to make of their services thus giving the waste management companies a full control of waste collection and management resulting in sustainable waste management in the study area.
\end{abstract}

Keywords: Solid waste, Management, Techniques, Ado-Ekiti and Nigeria

\section{Introduction}

From the pre-historic times, the interaction of mankind with the environment has resulted in the generation of wastes. These wastes were usually from the animals they slaughter for food or the remnants of wood cut 
for shelter. However, with the industrial revolution and subsequent steady rise in technological advancement, the nature of waste generated through human activities gradually assumed more complex forms. The complexity of these wastes generated necessitated the adoption for sustainable waste management to mitigate its negative impact on the environment. As humans, we are part of the environment and the ways we interact with it influences the quality of our lives. This was further buttressed by Kyei (2008) who opined that in man's attempt to obtain his basic needs, including the satisfaction of their nutritional requirements, he (mankind) interacts with the environment on a daily basis, resulting in the generation of unwanted materials.

Nigeria among other Third World Countries is witnessing an unprecedented growth of cities in recent times due to rural-urban influx. This influx is attributed to the uneven distribution of resources at the detriment of the rural centres. Hence the working population congregating at the urban centres, state capitals inclusive in search of "greener pasture" thus contributing to the urban population. This is evidenced from the estimated rate of urbanization or urban expansion of which the higher growth figure of above $6 \%$ have been recorded in major cities of Nigeria such as Lagos, Ibadan, Kaduna, Port-Harcourt, Warri e.t.c (Ogwueleka, 2009). with the pressure in urban population, existing facilities such as, water, electricity, road, educational institution, housing become inadequate and solid waste generation and disposal take unprecedented precarious dimension.

For instance, it is estimated that the rate of solid waste generated is about $0.43 \mathrm{~kg} / \mathrm{head}$ per day and 60 to 80 percent of it are organic in nature (Ogwueleka, 2009). Lagos alone generates over 10,000 metric tons of solid waste daily (WHO, 2006). The volume of solid waste generated sometimes over-whelm urban administrator's capacity to plan for their collection and disposal. Attempts to solve this problem effectively have given rise to myriad of strategies involving sizeable amount of capital and human resources. These strategies yielded little or no positive impact on the physical urban environment of Nigeria cities (Kayode and Omole, 2011). It may seem as though that urban waste management issues are difficult to deal with, however, the root cause sterns from the fact that the rate of collection and evacuation is inversely proportional to the rate of generation which makes solid waste accumulation a major source of environmental nuisance in Nigerian cities (Uwadiegwu and Chukwu, 2013).

Shaful and Mansoor (2003) affirms with this by stating that waste disposal became a problem with the building up of towns and cities where large numbers of people started gathering in relatively small areas in pursuit of livelihoods, which resulted in a huge volume of waste generated in the cities on a daily basis, whose call for proper handling in order to protect the environment and the population were not heeded (Fakere, Fadairo and Oriye, 
2012). Based on this, the need to manage solid wastes effectively to ensure that cities provide healthy and liveable environment became important.

In South West Nigeria, Ekiti State to be precise, cleanliness is embraced as a virtue but most of the time the perception of cleanliness is restricted to one's immediate environs with little care for what happens outside their households. The belief is that government is responsible for the environment, hence, one should not be bothered (Kyei, 2008). This is the typical case of Ado-Ekiti, the state capital where everyone thinks about his/her surrounding without concern for the general environment. The resultant effect of this perception is that many households dispose their waste products through drainage channels along the streets, without any concern for the sanitary condition of the environment. The deleterious effects which accompanies such an act includes health hazards, ground water contamination, pollution of agricultural (irrigation) water, blockage of drainages, gutters and other passages thus causing serious flooding at Adebayo, Ajilosun and Atikankan areas of Ado-Ekiti. In addition, this unhealthy habit has created more breeding spaces for insects, pests, rodents and vectors of diseases like dysentery diarrhoea and typhoid. It is against this backdrop that this paper seeks to examine the Solid Waste Management Techniques in Ado-Ekiti, South West, Nigeria.

The specifics objectives are;

- identify the categories of solid waste generated in the study area

- examine the methods adopted by the residents in managing their solid waste.

From the aforementioned objectives, the following hypotheses were formulated;

$>\mathbf{H}_{\mathbf{0}}$ : There is no significant difference in the categories of solid waste generated in the Study area.

$>\mathbf{H}_{\mathbf{0}}$ : There is no significant difference in the method adopted by respondents in the management of solid waste in the study area.

\section{The Study Area}

The study area is Ado- Ekiti, Ekiti State, Ado-Ekiti, an ancient city in Nigeria is located between latitudes $7^{0} 33^{1}$ and $7^{0} 43^{1}$ North of the equator and longitudes $5^{0} 07^{1}$ and $5^{0} 22^{1}$ East of the Greenwich meridian. It covers approximately $5888.9 \mathrm{~km}^{2}$ bounded by Kwara State to the North, Kogi State to the East, Osun State to the West and Ondo State to the South. The State is mainly an upland zone, rising over $250 \mathrm{~m}$ above sea level and with rock outcrops.

Ado-Ekiti has a total population of 313,690 people going by the 2006 Population Census (NBC, 2007), with the upsurge in urbanization trend in the 
region. The projected population as at 2017 using a growth rate of $2.5 \%$ stands at 411,553 . An increase in population will naturally lead to an increase in the amount, complexity and types of waste generated (Ogwueleka, 2009). In AdoEkiti, a corresponding increase has equally been evident as seen in the inability of the waste management agencies to handle and manage the waste generated by an ever increasing population (Ibimilua and Ibimilua, 2015).

Commercial activities in Ado-Ekiti are considered as one of the major factors contributing significantly to the generation of waste because traders do away with cans, papers, nylon, leaves e.t.c during trading transactions. The composition of waste generated in Ado-Ekiti are predominantly food remnants, followed by plastic, rubber, nylon and polythenes ash and dust, papers and cartons as well as leather and skin. Others are tin and metal, broken bottles and glass, wooden materials, rags and textiles, as well as aluminum, (Ibimilua and Ibimilua, 2015).

In the study area, the predominant method of waste disposal in the study area are; disposal at public units to be collected by the Ekiti State Waste Management Authority (ESWMA), collection by vendors, burning, burying, composting, on-street dumping, e.t.c.

\section{Methodology}

Data for the study were collected from both primary and secondary sources. The methodology for primary data collection were preliminary study, observation, and administration of questionnaires.

Questionnaire was designed using Likert scale (Likert, 1932) and was designed to capture the objective of the study. The questionnaire ascertained; the categories and sources of solid waste generated and the method adopted by the pubic in managing their waste

The population of the study area is 313,690 (NBS, 2007), however with an annual population increase of $2.5 \%$ (NBS, 2007), the population of the study area is projected to be approximately 411,553 in 2017. From the projected population of the study area the sample size of 400 was determined using Yaro Yemani's (1964) equation.

For field data collection, simple random sampling method was used. The study area was grouped into five zones (A, B, C, D, E). Table 1.1 show zones $(\mathrm{ABCDE})$ and the various streets under each zone. 
Table 1.1: Zones in the study area and the streets under each of the zones

\begin{tabular}{|c|c|c|c|c|}
\hline Zone A & Zone B & Zone C & Zone D & Zone E \\
\hline Adebayo & Ajilosun & Odo-Ado & Basiri & Ijigbo \\
\hline Similoluwa & Moferere & Igirigiri & Egbewa & Okeyinmi \\
\hline $\begin{array}{c}\text { State Hospital } \\
\text { School of } \\
\text { Nursing }\end{array}$ & Omolayo/Olujoda & Olokemeji & Falegan & Ojumose \\
\hline Nova & Gbajumo & Bola clinic & Ile-Abiye & Okesa \\
\hline Opopogbooro & Oke-Oniyo & Ureje & $\begin{array}{c}\text { Government } \\
\text { Reserve Area } \\
\text { (GRA) }\end{array}$ & Trona \\
\hline $\begin{array}{c}\text { Federal/State } \\
\text { Housing }\end{array}$ & Oke-Bola & Poly road & New Iyin Road & $\begin{array}{c}\text { Dallimore or } \\
\text { Stadium road }\end{array}$ \\
\hline Adehun & Ekute & \multicolumn{3}{|l}{} \\
\hline Pathfinder & & Bank Road & \\
\hline
\end{tabular}

(Field work, 2017)

Eighty (80) questionnaires were administered on respondents in each zone. Across the five zones a total of 400 copies of questionnaire were administered, out of which 395 were retrieved on the spot to ensure a $98.8 \%$ returns, with all being good and used for analysis.

Secondary data were collected mainly from Ekiti State Waste Management Authority, National Bureau of Statistics as well as from GIS Spatial Nigeria Limited. Data were analysed using tables, frequencies and percentages. The hypotheses earlier formulated were tested using Chi-square test.

\section{Results and Discussion}

On the categories of solid waste generated in Zone A, Table 1.2 showed that $64(80 \%)$ of the total sample agreed on generation of paper waste, $12(15 \%)$ disagreed and $4(5 \%)$ strongly disagreed. Regarding generation of empty cans/bottles as wastes, 79(98.8\%) agreed while 1(1.2\%) strongly disagreed. 219(26.3\%) respondents disagreed on generation of food remnants as wastes and 59(73.8\%) strongly disagreed. On whether plastics/polythene bags are waste generated in the study area, all the respondents; $80(100 \%)$ strongly agreed. On the generation of wood as wastes in Zone A, 6(7.5\%) strongly agreed, 61(76.3\%) disagreed while 13(16.3\%) strongly disagreed. $5(6.3 \%)$ respondents strongly agreed that metals are generated as wastes, $41(51.3 \%)$ disagreed while 34(42.5\%) strongly disagreed. This implies that papers, empty cans/bottles, plastics/polythene bags are the categories and sources of solid waste generated in Zone A. 
Table 1.2: Categories of solid waste generated in Zone A

\begin{tabular}{|c|c|c|c|c|c|c|}
\hline & Perception Statements & $\begin{array}{l}\text { Strongly } \\
\text { Agree (SA) }\end{array}$ & $\begin{array}{l}\text { Agree } \\
\text { (A) }\end{array}$ & $\begin{array}{l}\text { Undecided } \\
\text { (U) }\end{array}$ & $\begin{array}{l}\text { Disagree } \\
\text { (D) }\end{array}$ & $\begin{array}{l}\text { Strongly } \\
\text { Disagree } \\
\text { (SD) }\end{array}$ \\
\hline (a) & Papers as wastes in the area & - & $\begin{array}{l}64 \\
(80.0)\end{array}$ & - & $\begin{array}{l}12 \\
(15.0)\end{array}$ & $\begin{array}{l}4 \\
(5.0)\end{array}$ \\
\hline (b) & $\begin{array}{l}\text { Empty cans/ bottles as } \\
\text { wastes in the area }\end{array}$ & $\begin{array}{l}0 \\
(0.0)\end{array}$ & $\begin{array}{l}79 \\
98.8) \\
\end{array}$ & - & - & $\begin{array}{l}1 \\
(1.2) \\
\end{array}$ \\
\hline (c) & $\begin{array}{l}\text { Food Remnants as wastes in } \\
\text { the area }\end{array}$ & $\begin{array}{l}0 \\
(0.0) \\
\end{array}$ & $\begin{array}{l}0 \\
(0.0) \\
\end{array}$ & $\begin{array}{l}0 \\
(0.0)\end{array}$ & $\begin{array}{l}21 \\
(26.3)\end{array}$ & $\begin{array}{l}59 \\
(73.8)\end{array}$ \\
\hline (d) & $\begin{array}{l}\text { Plastic/polythene bags as } \\
\text { wastes in the area }\end{array}$ & $\begin{array}{l}80 \\
(100.0)\end{array}$ & $\begin{array}{l}0 \\
(0.0)\end{array}$ & $\begin{array}{l}0 \\
(0.0)\end{array}$ & $\begin{array}{l}0 \\
(0.0)\end{array}$ & $\begin{array}{l}0 \\
(0.0)\end{array}$ \\
\hline (e) & Wood as wastes in the area & $\begin{array}{l}6 \\
(7.5) \\
\end{array}$ & $\begin{array}{l}0 \\
(0.0)\end{array}$ & $\begin{array}{l}0 \\
(0.0) \\
\end{array}$ & $\begin{array}{l}61 \\
(76.3) \\
\end{array}$ & $\begin{array}{l}13 \\
(16.3)\end{array}$ \\
\hline (f) & Metals as wastes in the area & $\begin{array}{l}5 \\
(6.3) \\
\end{array}$ & $\begin{array}{l}0 \\
(0.0)\end{array}$ & $\begin{array}{l}0 \\
(0.0)\end{array}$ & $\begin{array}{l}41 \\
(51.3)\end{array}$ & $\begin{array}{l}34 \\
(42.5)\end{array}$ \\
\hline
\end{tabular}

Source: Field Work, 2017

Table 1.3 presents the categories and sources of solid waste generated in Zone B. The result revealed that 5(6.3\%) strongly agreed on the generation of papers as wastes, 55(68.8\%) agreed, 4(5\%) undecided and 16(20\%) disagreed. Regarding the generation of empty cans/bottles as wastes, $18(22.5 \%)$ strongly agreed, 61(76.3\%) agreed and 1(1.3\%) disagreed. $2(2.5 \%)$ respondents strongly agreed on the generation of food remnants as wastes in the area, 2(2.5\%) agreed, 1(1.3\%) undecided, 26(32.5\%) disagreed and $49(61.3 \%)$ strongly disagreed. Regarding the generation of plastic/polythene bags as wastes in the zone, $77(96.3 \%)$ strongly agreed, $2(2.5 \%)$ agreed while $1(1.3 \%)$ disagreed. $9(11.3 \%)$ strongly agreed on the generation of wood as wastes, $1(1.3 \%)$ agreed, $18(22.5 \%)$ disagreed and 52(65\%) strongly disagreed. $10(12.5 \%)$ respondents strongly agreed that metal wastes were being generated in the area, 7(8.8\%) disagreed and 63(78.8\%) strongly disagreed. It implies that papers, empty cans/bottles, plastic/polythene are categories and sources of solid waste generated in Zone B.

Table 1.3: Categories of solid waste generated in Zone B

\begin{tabular}{|l|l|l|l|l|l|l|}
\hline & Perception Statements & SA & A & U & D & SD \\
\hline (a) & Papers as wastes in the area & 5 & 55 & 4 & 16 & 0 \\
& & $(6.3)$ & $(68.8)$ & $(5.0)$ & $(20.0)$ & $(0.0)$ \\
\hline (b) & Empty cans/ bottles as wastes in the area & 18 & 61 & 0 & 1 & 0 \\
& & $(22.5)$ & $(76.3)$ & $(0.0)$ & $(1.3)$ & $(0.0)$ \\
\hline (c) & Food Remnants as wastes in the area & 2 & 2 & 1 & 26 & 49 \\
& & $(2.5)$ & $(2.5)$ & $(1.3)$ & $(32.5)$ & $(61.3)$ \\
\hline (d) & Plastic/polythene bags as wastes in the & 77 & 2 & 0 & 1 & 0 \\
& area & $(96.3)$ & $(2.5)$ & $(0.0)$ & $(1.3)$ & $(0.0)$ \\
\hline (e) & Wood as wastes in the area & 9 & 1 & 0 & 18 & 52 \\
& & $(11.3)$ & $(1.3)$ & $(0.0)$ & $(22.5)$ & $(65.0)$ \\
\hline (f) & Metals as wastes in the area & 10 & 0 & 0 & 7 & 63 \\
& & $(12.5)$ & $(0.0)$ & $(0.0$ & $(8.8)$ & $(78.8)$ \\
\hline
\end{tabular}

Source: Field Work, 2017 
Table 1.4 presents the categories and sources of solid waste generated in Zone C. The result showed that plastic/polythene bags, papers, empty cans/bottles and wood are categories and sources of solid waste generated in Zone C.

Table 1.4: Categories of solid waste generated in Zone $C$

\begin{tabular}{|c|c|c|c|c|c|c|}
\hline & Perception Statements & SA & A & $\mathrm{U}$ & $\mathrm{D}$ & SD \\
\hline (a) & Papers as wastes in the area & $\begin{array}{l}20 \\
(25.0)\end{array}$ & $\begin{array}{l}40 \\
(50.0)\end{array}$ & $\begin{array}{l}0 \\
(0.0)\end{array}$ & $\begin{array}{l}19 \\
(23.8)\end{array}$ & $\begin{array}{ll}1 \\
(1.3)\end{array}$ \\
\hline (b) & $\begin{array}{l}\text { Empty cans/ bottles as wastes in the } \\
\text { area }\end{array}$ & $\begin{array}{l}1 \\
(1.3)\end{array}$ & $\begin{array}{l}77 \\
(96.3)\end{array}$ & $\begin{array}{ll}0 \\
(0.0)\end{array}$ & $\begin{array}{l}0 \\
(0.0)\end{array}$ & $\begin{array}{l}2 \\
(2.5)\end{array}$ \\
\hline (c) & Food Remnants as wastes in the area & $\begin{array}{l}1 \\
(1.3)\end{array}$ & $\begin{array}{l}0 \\
(0.0) \\
\end{array}$ & $\begin{array}{l}0 \\
(0.0)\end{array}$ & $\begin{array}{l}42 \\
(52.5) \\
\end{array}$ & $\begin{array}{l}37 \\
(46.3) \\
\end{array}$ \\
\hline (d) & $\begin{array}{l}\text { Plastic/polythene bags as wastes in } \\
\text { the area }\end{array}$ & $\begin{array}{l}76 \\
(95.0)\end{array}$ & $\begin{array}{l}0 \\
(0.0)\end{array}$ & $\begin{array}{l}0 \\
(0.0)\end{array}$ & $\begin{array}{l}2 \\
(2.5)\end{array}$ & $\begin{array}{l}2 \\
(2.5)\end{array}$ \\
\hline (e) & Wood as wastes in the area & $\begin{array}{l}11 \\
(13.8)\end{array}$ & $\begin{array}{l}0 \\
(0.0) \\
\end{array}$ & $\begin{array}{ll}1 \\
(1.3)\end{array}$ & $\begin{array}{l}44 \\
(55.0)\end{array}$ & $\begin{array}{l}24 \\
(30.0) \\
\end{array}$ \\
\hline (f) & Metals as wastes in the area & $\begin{array}{l}9 \\
(11.3)\end{array}$ & $\begin{array}{l}0 \\
(0.0)\end{array}$ & $\begin{array}{l}0 \\
(0.0)\end{array}$ & $\begin{array}{l}42 \\
(52.5)\end{array}$ & $\begin{array}{l}29 \\
(36.3)\end{array}$ \\
\hline
\end{tabular}

Source: Field Work, 2017

Table 1.5 presents the categories and sources of solid waste generated in Zone D. The results showed that the categories and sources of solid waste generated in the zone are papers, empty cans/bottles and plastic/polythene bags.

Table 1.5: Categories of solid waste generated in Zone D

\begin{tabular}{|l|l|l|l|l|l|l|}
\hline & Perception Statements & SA & A & U & D & SD \\
\hline (a) & Papers as wastes in the area & 17 & 34 & 0 & 23 & 1 \\
& & $(22.7)$ & $(45.3)$ & $(0.0)$ & $(30.7)$ & $(1.3)$ \\
\hline (b) & Empty cans/ bottles as wastes in the & 1 & 71 & 0 & 0 & 3 \\
& area & $(1.3)$ & $(94.7)$ & $(0.0)$ & $(0.0)$ & $(4.0)$ \\
\hline (c) & Food Remnants as wastes in the area & 2 & 0 & 0 & 35 & 38 \\
& & $(2.7)$ & $(0.0)$ & $(0.0)$ & $(46.7)$ & $(50.7)$ \\
\hline (d) & Plastic/polythene bags as wastes in & 70 & 0 & 0 & 3 & 2 \\
& the area & $(93.3)$ & $(0.0)$ & $(0.0)$ & $(4.0)$ & $(2.7)$ \\
\hline (e) & Wood as wastes in the area & 16 & 0 & 1 & 37 & 21 \\
& & $(21.3)$ & $(0.0)$ & $(1.3)$ & $(49.3)$ & $(28.0)$ \\
\hline (f) & Metals as wastes in the area & 9 & 0 & 0 & 38 & 28 \\
& & $(12.0)$ & $(0.0)$ & $(0.0)$ & $(50.7)$ & $(37.3)$ \\
\hline
\end{tabular}

Source: Field Work, 2017

Table 1.6 presents the categories and sources of solid waste generated in Zone E. The result showed that papers, empty cans/bottles, plastics/polythene bags are categories and sources of solid wastes generated in Zone E. 
Table 1.6: Categories of solid waste generated in Zone E

\begin{tabular}{|c|c|c|c|c|c|c|}
\hline & Perception Statements & SA & $\mathbf{A}$ & $\mathbf{U}$ & $\mathbf{D}$ & SD \\
\hline (a) & Papers as wastes in the area & $\begin{array}{l}8 \\
(10.0) \\
\end{array}$ & $\begin{array}{l}55 \\
(68.8) \\
\end{array}$ & $\begin{array}{l}0 \\
(0.0)\end{array}$ & $\begin{array}{l}10 \\
(12.5)\end{array}$ & $\begin{array}{l}7 \\
(8.8) \\
\end{array}$ \\
\hline (b) & $\begin{array}{l}\text { Empty cans/ bottles as wastes in the } \\
\text { area }\end{array}$ & $\begin{array}{l}11 \\
(13.8)\end{array}$ & $\begin{array}{l}67 \\
(83.8)\end{array}$ & $\begin{array}{l}0 \\
(0.0)\end{array}$ & $\begin{array}{l}0 \\
(.0)\end{array}$ & $\begin{array}{l}2 \\
(2.5)\end{array}$ \\
\hline (c) & Food Remnants as wastes in the area & $\begin{array}{l}2 \\
(2.5) \\
\end{array}$ & $\begin{array}{l}1 \\
(1.3)\end{array}$ & $\begin{array}{ll}0 \\
(0.0)\end{array}$ & $\begin{array}{l}19 \\
(23.8)\end{array}$ & $\begin{array}{l}58 \\
(72.5)\end{array}$ \\
\hline (d) & $\begin{array}{l}\text { Plastic/polythene bags as wastes in } \\
\text { the area }\end{array}$ & $\begin{array}{l}76 \\
(95.0)\end{array}$ & $\begin{array}{l}2 \\
(2.5)\end{array}$ & $\begin{array}{l}0 \\
(0.0)\end{array}$ & $\begin{array}{l}0 \\
(0.0)\end{array}$ & $\begin{array}{l}2 \\
(2.5) \\
\end{array}$ \\
\hline (e) & Wood as wastes in the area & $\begin{array}{l}5 \\
(6.3)\end{array}$ & $\begin{array}{l}1 \\
(1.3)\end{array}$ & $\begin{array}{l}0 \\
(0.0)\end{array}$ & $\begin{array}{l}54 \\
(67.5)\end{array}$ & $\begin{array}{l}20 \\
(25.0)\end{array}$ \\
\hline (f) & Metals as wastes in the area & $\begin{array}{l}6 \\
(7.5)\end{array}$ & $\begin{array}{l}0 \\
(0.0)\end{array}$ & $\begin{array}{l}0 \\
(0.0)\end{array}$ & $\begin{array}{l}26 \\
(32.5)\end{array}$ & $\begin{array}{l}48 \\
(60.0)\end{array}$ \\
\hline
\end{tabular}

Source: Field Work, 2017

Table 1.7 presents the categories and sources of solid waste generated in the study area. The result consistently revealed that papers, empty cans/bottles and plastic/polythene bags are the major categories of solid waste generated in the study area.

Table 1.7: Categories of solid waste generated in the study area

\begin{tabular}{|l|l|l|l|l|l|l|}
\hline & Perception statement & SA & A & U & D & SD \\
\hline (a) & Papers as wastes in the area & 50 & 248 & 4 & 80 & 13 \\
& & $(12.7)$ & $(62.8)$ & $(1.0)$ & $(20.3)$ & $(3.3)$ \\
\hline (b) & Empty cans/ bottles as wastes in the & 31 & 355 & 0 & 1 & 8 \\
& area & $(7.8)$ & $(89.9)$ & $(0.0)$ & $(0.3)$ & $(2.0)$ \\
\hline (c) & Food Remnants as wastes in the area & 7 & 3 & 1 & 143 & 241 \\
& & $(1.8)$ & $(0.8)$ & $(0.3)$ & $(36.2)$ & $(61.0)$ \\
\hline (d) & Plastic/polythene bags as wastes in & 379 & 4 & 0 & 6 & 6 \\
& the area & $(95.9)$ & $(1.0)$ & $(0.0)$ & $(1.5)$ & $(1.5)$ \\
\hline (e) & Wood as wastes in the area & 47 & 2 & $2(0.5)$ & 214 & 130 \\
& & $(11.9)$ & $(0.5)$ & & $(54.2)$ & $(32.9)$ \\
\hline (f) & Metals as wastes in the area & 39 & 0 & 0 & 154 & 202 \\
& & $(9.9)$ & $(0.0)$ & $(0.0)$ & $(39.0)$ & $(51.1)$ \\
\hline
\end{tabular}

Source: Field Work, 2017

For Zones A and B, waste materials such as paper, empty cans, bottles and plastics are mostly generated due to the fact that educational land use such as Ekiti State University and Federal Polytechnic Ado-Ekiti are present in these zones respectively, they also serve as a residential zone to both the students and the lecturers of these institutions. For Zones $\mathrm{C}$ and $\mathrm{E}$, where the popular Ojaoba and Fayose Market are located generate mostly plastic nylon bags and food raminants due to the buying and selling of perishable and non- 
perishable goods which they need the plastic nylon bags for packaging of these goods for their customers.

On a zonal basis there is a homogeneity in the categories of waste generated across zones. However, In zones where we have people generating metals and woods like Zone D it implies that there are a sizable number of artisans in the likes of welders and carpenters who due to their operations generate Metals and Wood respectively.

Table 1.9 presents the methods adopted by the populace in managing their solid waste in the study area. The result revealed that dumping of waste in public disposal units for it to be collected; 322(81.5\%) was a popular method solid waste disposal in Zone $\mathrm{E}$ while leaving the waste for Waste Management Company personnel to come and collect it; 190(39.1\%) and leaving the waste for local waste collect (informal sector) to come and collect it; $142(36 \%)$ were sometimes adopted as methods for solid waste disposal in the zone. This implies that dumping the waste in public disposal units for it to be collected constitutes the most method adopted by the populace in managing their solid waste in the study area.

Table 1.8: Methods adopted by the Respondents in managing solid waste in the study area

\begin{tabular}{|c|c|c|c|c|c|c|}
\hline & Perception statements & $\mathbf{S A}$ & $\mathbf{A}$ & $\mathbf{U}$ & D & SD \\
\hline (a) & Burn the waste generated. & $\begin{array}{r}32 \\
(8.1)\end{array}$ & $\begin{array}{l}11 \\
(2.8)\end{array}$ & $\begin{array}{l}0 \\
(0.0)\end{array}$ & $\begin{array}{l}276 \\
(69.9)\end{array}$ & $\begin{array}{l}76 \\
(19.2)\end{array}$ \\
\hline (b) & $\begin{array}{l}\text { Bury the waste generated for them to } \\
\text { decompose and form compost. } \\
\text { (Composting) }\end{array}$ & $\begin{array}{l}7 \\
(1.8)\end{array}$ & $\begin{array}{l}2 \\
(0.5)\end{array}$ & $\begin{array}{l}0 \\
(0.0)\end{array}$ & $\begin{array}{l}227 \\
(57.5)\end{array}$ & $\begin{array}{l}159 \\
(40.3)\end{array}$ \\
\hline (c) & $\begin{array}{l}\text { Dump the waste in public disposal } \\
\text { units for it to be collected. }\end{array}$ & $\begin{array}{l}315 \\
(79.7)\end{array}$ & $\begin{array}{l}7 \\
(1.8)\end{array}$ & $\begin{array}{l}1 \\
(0.3)\end{array}$ & $\begin{array}{l}48 \\
(12.2)\end{array}$ & $\begin{array}{l}24 \\
(6.1)\end{array}$ \\
\hline (d) & $\begin{array}{l}\text { Leave the waste for the Waste } \\
\text { Management Company personnel to } \\
\text { come and collect it. }\end{array}$ & $\begin{array}{l}150 \\
(38.0)\end{array}$ & $\begin{array}{l}40 \\
(10.1)\end{array}$ & $\begin{array}{l}1 \\
(0.3)\end{array}$ & $\begin{array}{l}147 \\
(37.2)\end{array}$ & $\begin{array}{l}57 \\
(14.4)\end{array}$ \\
\hline (e) & $\begin{array}{l}\text { Leave the waste for the local waste } \\
\text { collectors (Informal sector) to come } \\
\text { and collect it. }\end{array}$ & $\begin{array}{l}139 \\
(35.2)\end{array}$ & $\begin{array}{l}3 \\
(0.8)\end{array}$ & $\begin{array}{l}0 \\
(0.0)\end{array}$ & $\begin{array}{l}164 \\
(41.5)\end{array}$ & $\begin{array}{l}89 \\
(22.5)\end{array}$ \\
\hline (f) & Recycle some of the waste I generate. & $\begin{array}{l}7 \\
(1.8)\end{array}$ & $\begin{array}{l}0 \\
(0.0)\end{array}$ & $\begin{array}{l}0 \\
(0.0)\end{array}$ & $\begin{array}{l}225 \\
(57.0)\end{array}$ & $\begin{array}{l}163 \\
(41.3)\end{array}$ \\
\hline
\end{tabular}

Source: Field Work, 2017

A general overview across Zones in the study area has showed that majority of the respondents choose the most cost effective method of disposing their waste which is disposal using the public bins. This is so because According to a director with Ekiti State Waste Management Authority (EKSWMA), Zone A is among the places covered by EKSWMA as a result the populace resort to dumping their waste along the curbside to be picked by 
the waste trucks. In addition no fee is charged for dumping these wastes there as such the populace they prefer to dump rather than pay for it to be collected. However, the story is different in some part of Zones. For instance in places like Fayose Market which was among the areas in Zone B. It was observed that there were waste bins all over the place and the environment was kept clean. Upon inquiry, It was learnt that it was mandatory for them to keep in front of their shops clean because if the Waste Management Authority should find a shop whose environment is dirty, that shop will be locked up and the owner fined. They were equally compelled to pay dues of N500 to a designated bank account for the services rendered by the Ekiti State Waste Management Authority who come every Thursday to collect the wastes in the dust bins. The N500 monthly dues, they complained that it was expensive. Even though the Market Environment was clean, the drainage in Atikankan flows through the market's back gate which the respondents complained that it affected them negatively because it was unsightly.

For person's who live far off the waste bins, most of them contract the Private Waste management Companies to come and collect their waste and pay an average monthly fee of N2,000.00 per month. Others who cannot afford such luxury contract the informal Waste collectors to come buy some of the plastics and other recyclable materials from them after which they either burn or bury the remaining wastes.

\section{Hypotheses Testing}

To further ascertain whether there exist a significant difference in the categories of solid waste generated in the study area, a hypothesis was formulated and tested statistically.

\section{Hypothesis 1}

$\mathbf{H}_{\mathbf{0}}$ : There is no significant difference in the categories of solid waste generated in the study area.

$\mathbf{H}_{\mathbf{i}}$ : There is significant difference in the categories of solid waste generated in the study area.

Table 1.9: Chi-square $\left(\chi^{2}\right)$ analysis showing the categories of waste generated in the study area

\begin{tabular}{|c|c|c|c|c|c|c|c|c|c|c|}
\hline $\mathbf{S} / \mathbf{N}$ & PERCEPTION STATEMENTS & SA & A & $\mathbf{U}$ & D & SD & TOTAL & df & $\chi^{2}$ & $\mathbf{P}$ \\
\hline (a) & Papers as wastes in the area & 50 & 248 & 4 & 80 & 13 & 395 & \multirow{7}{*}{$\begin{array}{l}2 \\
5\end{array}$} & \multirow{7}{*}{ 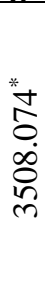 } & \multirow{7}{*}{ ஜ } \\
\hline (b) & Empty cans/bottles as wastes in the area & 31 & 355 & 0 & 1 & 8 & 395 & & & \\
\hline (c) & Food remnants as wastes in the area & 7 & 3 & 1 & 143 & 241 & 395 & & & \\
\hline (d) & Plastic/polythene bags as wastes in the area & 379 & 4 & 0 & 6 & 6 & 395 & & & \\
\hline (e) & Wood as wastes in the area & 47 & 2 & 2 & 214 & 130 & 395 & & & \\
\hline \multirow[t]{2}{*}{ (f) } & Metals as waste in the area & 39 & 0 & 0 & 154 & 202 & 395 & & & \\
\hline & $\begin{array}{r}\text { TOTAL } \\
\end{array}$ & 553 & 612 & 7 & 598 & 600 & 2370 & & & \\
\hline
\end{tabular}

Source: Field work, 2017 
Table 1.9 shows that there is significant difference in the categories of solid waste generated in the study area $\left(\chi^{2}=3508.074, \mathrm{df}=25, \mathrm{p}<0.05\right)$. Therefore, the null hypothesis $\left(\mathrm{H}_{\mathrm{o}}\right)$ is rejected while the alternate hypothesis $\left(\mathrm{H}_{\mathrm{i}}\right)$ is accepted.

The significant difference observed affirms to the fact that the operational land use in a particular zone gives rise to differences in the amount and types of solid waste generated in a particular zone.

\section{Hypothesis 2}

$\mathbf{H}_{0}$ : There is no significant difference in the method adopted by respondents in the management of solid waste in the study area.

$\mathbf{H}_{\mathbf{i}}$ : There is significant difference in the method adopted by respondents in the management of solid waste in the study area.

Table 1.10: Chi-square $\left(\chi^{2}\right)$ analysis showing the methods of waste management in the study area

\begin{tabular}{|c|c|c|c|c|c|c|c|c|c|c|}
\hline $\mathbf{S} / \mathbf{N}$ & PERCEPTION STATEMENTS & SA & $\mathbf{A}$ & $\mathbf{U}$ & D & SD & $\begin{array}{l}\text { ROW } \\
\text { TOTAL } \\
\text { (RT) }\end{array}$ & df & $\underset{2}{\chi}$ & $\mathbf{p}$ \\
\hline (a) & Burn the waste generated. & 32 & 11 & 0 & 276 & 76 & 395 & \multirow{7}{*}{$\begin{array}{l}2 \\
0\end{array}$} & & \\
\hline (b) & $\begin{array}{l}\text { Bury the waste generated for them to } \\
\text { decompose and form compost } \\
\text { (compositing). }\end{array}$ & 7 & 2 & 0 & 227 & 159 & 395 & & & \\
\hline (c) & $\begin{array}{l}\text { Dump the waste in public disposal } \\
\text { units for it to be collected. }\end{array}$ & 315 & 7 & 1 & 48 & 24 & 395 & & & \\
\hline (d) & $\begin{array}{c}\text { Leave the waste for the Waste } \\
\text { Management Company personnel to } \\
\text { come and collect it. }\end{array}$ & 150 & 40 & 1 & 147 & 57 & 395 & & & g \\
\hline (e) & $\begin{array}{l}\text { Leave the waste for the local waste } \\
\text { collectors (Informal sector) to come } \\
\text { and collect it. }\end{array}$ & 139 & 3 & 0 & 164 & 89 & 395 & & & \\
\hline \multirow[t]{2}{*}{ (f) } & Recycle some of the waste I generate. & 7 & 0 & 0 & 225 & 163 & 395 & & & \\
\hline & COLUMN TOTAL(CT) & 650 & 63 & 2 & $\begin{array}{c}108 \\
7\end{array}$ & 568 & 2370 & & & \\
\hline
\end{tabular}

" $\mathbf{p}<0.05$

Source: Field work, 2017

The result in Table 1.11 reveals that there is significant difference in the method adopted by respondents in the management of solid waste in the study area $\left(\chi^{2}=1124.770, \mathrm{df}=20, \mathrm{p}<0.05\right)$. Therefore, the null hypothesis $\left(\mathrm{H}_{\mathrm{o}}\right)$ is rejected while the alternate hypothesis $\left(\mathrm{H}_{\mathrm{i}}\right)$ is accepted.

This equally is a clear affirmation that proximity to dumpsites, waste collection fees and availability of Waste bins are contributing factors in deciding the Waste disposal Method adopted in each of the Zones. 


\section{Recommendations and Policy Implications}

Government should allocate more funds to solid waste management operations, to make room for adequate waste bins to be provided and situated at strategic positions within the city. This will reduce the incidence of indiscriminate waste disposal and debasement of the environment due to uncollected wastes. Furthermore, access to funds will lead to a provision of more waste equipments such as compaction trucks hence a reduction in the amount of uncollected wastes and less pressure will be put on the existing resources (equipments).

The cost of waste collection by the Waste Management Companies should be made affordable. This will encourage the people to subscribe to their services thus giving the waste management companies a full control of waste collection and management hence a sustainable waste management technique will be achieved. More waste dump centres should be provided for the waste companies. This will enable the populace to go to these dump centres to dump their wastes. By this habit of dumping wastes along the streets and curbsides will be reduced. Secondly, the government should support the waste management agencies with more waste disposal vehicles, this will reduce the incidence of delay in waste collection. In addition, the roads leading to the landfill sites should be repaired to reduce the rate at which these waste disposal vehicles break down during the course of their movement from the collection points to the landfill sites. Thirdly, Government should make available funds in form of loans to persons' who wish to join the waste management sector. With this initiative the government will reduce the burden of waste management on the Local Government Councils who have limited resources at their disposal to manage the incessant increase in the amount of waste generated.

Government by increasing the budgetary allocation for waste management Agencies will go a long way in motivating the agencies to carry out their waste management duties effectively. Equipment such as compactions trucks and waste bins should be provided at strategic points in the study area, to ensure proper solid waste management. Problems like delay in collection, waste bins being always full, indiscriminate waste disposal will hence be ameliorated. Lastly, more recycling firms for plastics, iron and aluminum e.t.c should be established. This programme if implemented will boost the activity of the informal waste collectors and more wastes will be recycled from the wastes stream thus leading to the longevity of our landfill sites. In addition, organic wastes should be processed in such a way as to produce fertilizers for our crops and general agricultural purpose. If this stated recommendations are implemented the waste management agencies will be able and capable to carry out their duties effectively and implement the reduce, reuse and recycle policy of sustainable waste management. 


\section{References:}

1. Adedibu, A.A., (1983): “A comparative analysis of waste generation in Ilorin and Offa, Kwara State". A Paper Presented at the National Conference on Development And Environment Organized by NISER, University of Ibadan, Nigeria.

2. Adewumi, I.K. and Aadefolalu A.A (2005): "Planning Organic Fertilizer

3. Industries for Municipal Solid Wastes Management" Journal of Applied Sciences Research 1 (3): 285291

4. Akpoghiran,.P., (2016): Environmental Management Awareness Campaign. Accessed on 03/01/2017 from http://akpatemac.com/2016/10/

5. Awopetu, M.S, Awopetu R.G., Sample E.D, Akinwale O. C, Olufiropo S. A, Fullen M.A., Booth C. A. and Hammond F.N., (2014): "Municipal Solid Waste Management and the role Of Waste pickers in Nigeria". International Journal of Education and Research Vol. 2 No 3

6. Fakere, A. A. Fadairo, G. and Oriye, O. (2012): "Domestic Waste Management and Urban Residential Environment: Focus on Akure, Nigeria". International Journal of Engineering and Technology 2 (5) 878-886

7. Glawe, U., C. Visvanathan and Alamgir M. (2005): "Solid waste management in least developed Asian countries". A Comparative Analysis International Conference on Integrated solid waste management in Southeast Asian cities, Siem Reap, Cambodia 5-7.

8. Hauwa, S.K (2013): An Assessment of Waste Generated In Ankpa Town, Kogi State University Anyigba, Kogi State.

9. Ibimilua A. F and Ibimilua F. O (2015): Categorization, Characterisation, Management and Future Trends of Solid Wastes in Ado-Ekiti, Nigeria. Mediterranean Journal of Social Sciences MCSER Publishing, Rome-Italy. 6 (4) pp 628-637

10. Jegede O.D (2016): "Assessment of the problems and prospects of solid waste management in Kabba, Kogi State, Nigeria". Unpublished master's thesis. Department of Geography and Planning Science, Ekiti State University, Ado- Ekiti.

11. Kayode, A. M. and Omole, F. K. (2011): "Some Socio-Economic Factors Affecting Solid Wastes Generation and Disposal in Ibadan Metropolis, Nigeria". Journal of Environmental Issues and Agriculture in Developing Countries. 3 (1) 55-64

12. Kyei, A. (2008): Solid domestic waste management practice in Afigye Sekyere district. Kwame Nkurumah University of Science and Technology, Kumasi, Ghana. 
13. Leton, T.G and Omotosho, .O. (2004): "Landfill Operation in Niger Delta Region of Nigeria". Engineering Geology 73 (12)1523.

14. Likert, R (1932): "A technique for the measurement of Attitudes". Archives of Psychology. No 140

15. Manyele SV, Kagonji I.S, and Mrisho .J. (2011): “Assessment of Medical Waste Incinerator Performance Based on Physical Characteristics of Ashes". Engineering. Journal. 3(10) pp 1045-1053.

16. Mensah, A and Larbi, E (2005): Quality Assuarance. Solid Waste Disposal in Ghana. http// www.tren.wastsan.net Accessed on $26^{\prime} 01^{\prime} 2017$

17. Mikkel Johannessen and Grabrieda Boyer (1999): "Observation of Solid Waste landfills in Developing Countries Urban Development Division". Waste Management Anchor Team. The World Bank

18. Ministry of Environment and Forest, Government of India (2012): State of the Environment and Related Issues, Uttah Pradash. Envis Center

19. National Bureau of Statistics NBS (2007): "National Population Commission Census Data, 2006. Accessed on 3/10/ 2016.from http://www.nigerianstat.gov.ng/

20. Ogwueleka T. C (2009): "Municipal solid Waste Characteristics and Management in Nigeria". Iran Journal of Environmental Health, Science and Engineering, vol. 6, No 3, pp 173-18

21. Onwughara, I.N, Nnorom, I.C and Kanno, O.C., (2010): "Issues of Roadside Disposal Habit of Municipal Solid Waste, Environmental Impacts and Implementation of Sound Management Practices in Developing Country Nigeria”. International journal of Environmental Science and Development Vol 1, No 5.

22. Osman S. S (2011): "Environmental Impacts of Solid waste disposal in Agbobloshie, A suburb of Accra Metropolotan Assembly" Unpublished thesis. Central University, Accra, Ghana.

23. Panin, A. (2012): Students' Handbook: Research methods. Central University College, Accra, Ghana.

24. Seo, S. (2004): "Environmental Impact of Solid Waste Treatment Methods in Korea" Journal of Engineering, 130 (1): 81-89.

25. Shafiul, A.A., and Mansoor, A. (2003): "Partnerships for solid waste management in developing countries: Linking theories to realities in the Institute of Development Engineering, Water and Development Centre (WEDC)". Loughborough University, United Kingdom

26. Smith S.E. (2012): "What is waste Management?" www.wisegeek.com Accessed 15/12/2016 
27. Sule, R.A.O. (2001): Control of Urban Environmental Pollution. A Case study of Synopsis; University of Calabar, Calabar, Cross River State.

28. United State Environment Protection Agency (2002): "What is Integrated Solid Waste management" www.epa.gov/globalwarming Accessed 20/09/2016

29. Uwadiegwu, B. O. and Chukwu, K.E. (2013): "Strategies for Effective Urban Solid Waste Management in Nigeria". European Scientific Journal 9 (8) 296- 308

30. Uzoma E.S.K and Ogunleye O.S (2017): "Solid Waste Disposal in Abossey Okai and its Impact on the Environment". Journal of Scientific and Engineering Research Vol. 4, No.6, pp 120-126

31. WHO (2006): Health of the People. The African Regional Health Report.

32. Yaro Yamani (1964): Statistics. An introductory Analysis, Third Edition, Harper and Row Publishers, New York, USA.

\section{APPENDIX}

\section{SECTION A}

\section{CHARACTERISTICS OF RESPONDENTS}

Please tick or fill in as appropriate

(1) Sex

(2) Age
(a) Male [
(b) Female [
(a) $18-29$ [ ]
(b) $30-45[$
] (c) $45-5$
(d) 51 and above [ ]

(3) Level of education?
(a) Primary sch
(b) SSCE [ ]
(c) ND - HND [ ]
(d)B.Sc. [
(e) M.Sc. [
] (f) Others: (Please specify)

(4) Occupation / Profession?
(a) Trader [ ]
(b) Public/Private worker
(c) Artisan [ ]

Other (please specify)

(5) For how long have you been living in this area?

(a) Less than a year [ ] (b) 1-2years [ ] (b) 3-5 years [ ] (c) 6-10 [ ]

(d) More than 10year [ ]

\section{SECTION (B).}

\section{CATEGORIES AND SOURCES OF SOLID WASTE GENERATED}

To what extent do you agree or disagree with the following statements.

Please Tick appropriately: SA = Strongly Agree, A = Agree, $\mathrm{U}=$ Undecided, SD= Strongly Disagree, $\mathrm{D}=$ Disagree. 
Categories of solid waste generated

\begin{tabular}{|l|l|l|l|l|l|l|}
\hline 6 & I generate ....... & SA & A & U & D & SD \\
\hline (a) & Papers as wastes in the area & & & & & \\
\hline (b) & Empty cans/ bottles as wastes in the area & & & & & \\
\hline (c) & Food Remnants as wastes in the area & & & & & \\
\hline (d) & Plastic/polythene bags as wastes in the area & & & & & \\
\hline (e) & Wood as wastes in the area & & & & & \\
\hline (f) & Metals as wastes in the area & & & & & \\
\hline
\end{tabular}

\section{Sources of solid waste generation}

\begin{tabular}{|l|l|l|l|l|l|l|}
\hline 7 & $\begin{array}{l}\text { The sources of solid wastes generated in the area } \\
\text { come from........ }\end{array}$ & SA & A & U & D & SD \\
\hline (a) & Domestic activities & & & & & \\
\hline (b) & Commercial activities & & & & & \\
\hline (c) & Agricultural activities & & & & & \\
\hline (d) & Industrial activities & & & & & \\
\hline
\end{tabular}

Rate of solid waste generation in the study area

\begin{tabular}{|l|l|l|l|l|l|l|}
\hline 8 & $\begin{array}{l}\text { There is a significant increase in the volume of } \\
\text { waste generated in your area. }\end{array}$ & A & U & D & SD \\
\hline 9 & $\begin{array}{l}\text { There is a significant decrease in the volume of } \\
\text { waste generated in your area. }\end{array}$ & & & & \\
\hline 10 & $\begin{array}{l}\text { Increase in population has led to an increase in the } \\
\text { volume of waste generated. }\end{array}$ & & & & \\
\hline 11 & $\begin{array}{l}\text { Increase in the consumption pattern has led to an } \\
\text { increase in the volume of waste generated. }\end{array}$ & & & & & \\
\hline & $\begin{array}{l}\text { Increase in the standard of living of people has led } \\
\text { to an increase in the volume of waste generated }\end{array}$ & & & & \\
\hline
\end{tabular}

\section{SECTION (C).}

METHODS ADOPTED BY THE POPULACE IN THE MANAGEMENT OF SOLID WASTE

\begin{tabular}{|l|l|l|l|l|l|l|}
\hline 13 & $\begin{array}{l}\text { To what extent do you agree or disagree with the } \\
\text { following statement. I....... }\end{array}$ & A & U & D & SD \\
\hline (a) & burn the waste generated. & & & & & \\
\hline (b) & $\begin{array}{l}\text { bury the waste generated for them to decompose } \\
\text { and form compost. (Composting) }\end{array}$ & & & & \\
\hline (c) & $\begin{array}{l}\text { dump the waste in public disposal units for it to be } \\
\text { collected. }\end{array}$ & & & & \\
\hline (d) & $\begin{array}{l}\text { leave the waste for the Waste management } \\
\text { Company personnel to come and collect it. }\end{array}$ & & & & \\
\hline (e) & $\begin{array}{l}\text { leave the waste for the local waste collectors } \\
\text { (Informal sector) to come and collect it. }\end{array}$ & & & & \\
\hline (f) & recycle some of the waste I generate & & & & & \\
\hline
\end{tabular}


(14) If you recycle, what materials do you recycle?

(a) Paper [ ] (b) Empty cans/bottle [ ] (c) Food remnants [ ] (d) Plastics/polythene bags [ ] (e) wood [ ] (f) Metals [ ] (g) Others please specify

SECTION (D).

\section{CHALLENGES INHIBITING ADEQUATE SOLID WASTE MANAGEMENT}

To what extent do you agree or disagree with the following statements.

Please Tick appropriately: SA = Strongly Agree, A = Agree, $\mathrm{U}=$ Undecided, $\mathrm{SD}=$ Strongly Disagree, $\mathrm{D}=$ Disagree.

\begin{tabular}{|l|l|l|l|l|l|l|}
\hline S/N & Variables & SA & A & U & D & SD \\
\hline 14 & $\begin{array}{l}\text { Inadequate dumpsite in the area is the cause of poor } \\
\text { solid waste management. }\end{array}$ & & & & \\
\hline 15 & $\begin{array}{l}\text { Dumpsite being far from the populace is the cause } \\
\text { of poor solid waste management }\end{array}$ & & & & & \\
\hline $\begin{array}{l}\text { The amount charged for waste collection and } \\
\text { dumping is not affordable hence a poor sanitary } \\
\text { situation }\end{array}$ & $\begin{array}{l}\text { Delay in collection of wastes leads to poor sanitary } \\
\text { conditions. }\end{array}$ & & & & & \\
\hline 18 & $\begin{array}{l}\text { Lack of public awareness on the importance of } \\
\text { good sanitary condition is the cause of Poor solid } \\
\text { waste management }\end{array}$ & & & & & \\
\hline 19 & $\begin{array}{l}\text { No monetary value attached to recycled waste } \\
\text { (Incentives) is the cause of poor solid waste } \\
\text { management. }\end{array}$ & & & & \\
\hline
\end{tabular}

(20) If waste is dumped in public disposal unit or skip, approximately, how many minutes does it take you to get to the site? (a) 5-10mins. [ ] (b) 11-15mins. [ ] (c) 16-20mins. [ ] (d) 21-25mins. [ ] (e) More than 25mins - 75mins [ ]

(21) If travelling more than $10 \mathrm{mins}$ to dispose of the waste inconveniences you, what do you do with the waste? I/ dump them in

(a) Nearest available space (b) Nearest gutter (c) Burn them (d) Bury them Other, specify.

(22). If you are charged, how much do the waste collectors charge? Indicate the amount in N.

Why the amount is charged not affordable to you? (You may skip this question if the amount charged is affordable) (a) I am not working [ ] (b) I don't see the need [ ] (c) My income is very small [ ] (d) practice of charging is new [ ] (e) other reason (Specify): 
SECTION (E)

EFFECTS OF SOLID WASTE GENERATION ON THE INHABITANTS OF THE STUDY AREA

To what extent do you agree or disagree with the following statements.

Please Tick appropriately: SA = Strongly Agree, $\mathrm{A}=$ Agree, $\mathrm{U}=$ Undecided, $\mathrm{SD}=$ Strongly Disagree, D = Disagree.

\begin{tabular}{|l|l|l|l|l|l|l|}
\hline 23 & Solid waste generation has led to........ & SA & A & U & D & SD \\
\hline (a) & $\begin{array}{l}\text { outbreak of diseases such as cholera, Malaria, } \\
\text { dysentery.. }\end{array}$ & & & & \\
\hline (b) & $\begin{array}{l}\text { a reduction in the aesthetic value of the } \\
\text { environment }\end{array}$ & & & & \\
\hline (c) & land pollution & & & & & \\
\hline (d) & water pollution & & & & & \\
\hline (e) & air pollution & & & & \\
\hline
\end{tabular}

\section{SECTION (F).}

\section{OPTIONS FOR IMPROVED SOLID WASTE MANAGEMENT IN} ADO-EKITI

To what extent do you agree or disagree with the following statements.

Please Tick appropriately: $\mathrm{SA}=$ Strongly Agree, $\mathrm{A}=$ Agree, $\mathrm{U}=$ Undecided, $\mathrm{SD}=$ Strongly Disagree, D = Disagree.

\begin{tabular}{|l|l|l|l|l|l|l|}
\hline 24 & $\begin{array}{l}\text { The public can be encouraged to get involved in } \\
\text { solid waste management by............ }\end{array}$ & SA & A & U & D & SD \\
\hline (a) & More waste containers should be provided & & & & & \\
\hline (b) & Provision of incentives for recycled wastes & & & & & \\
\hline (c) & Timely collection of wastes & & & & & \\
\hline (d) & Environmental education and awareness & & & & & \\
\hline (e) & Reducing cost of waste collection & & & & & \\
\hline (f) & Subsidizing the cost of waste bins & & & & & \\
\hline (g) & More approved dumpsites should be provided & & & & & \\
\hline
\end{tabular}

